\title{
IDENTIFIKASI POTENSI SARI BUAH JERUK MENJADI LISTRIK SEBAGAI SUMBER BELAJAR FISIKA MATERI ARUS LISTRIK SISWA SMP KELAS IX
}

\author{
Fitriyaningsih \\ Partono \\ Fakultas Keguruan dan Ilmu Pendidikan, Universitas Muhammadiyah Metro \\ Email:luckyboyrahmad@gmail.com \\ Email:partono66@gmail.com
}

\begin{abstract}
The purpose of this study was 1. To know potential of different citrus fruit juice varieties into electricity. 2. To know juice of citrus varieties that have the potential to be superior in electrical 3. To know piece of research that can be used as a learning resource. 4. To know learning resources that can be generated from the research. The place is a laboratory study was conducted of science, University of Muhammadiyah Metro May 25, 2014. Oranges juice were taken from five different varieties are citrus, lime, tangerine, grapefruit, and lime. There are three variations of existing experiments in the study of differences in varieties, differences in the distance between the electrodes, and the difference in volume. There are five treatments and five repetitions in this experiment. In the process the research data used ANOVA analysis of non-parametric Kruskal Wallis test. The experimental results showed that the juice that comes from different varieties have different potentials in into electricity. Lemon juice is the most superior varieties as electricity. Part of research that can be used as a learning resource that the pH value of each citrus varieties, the use of digital multitester, and the voltage generated. The results of this study can benefit as a learning resource in the form of worksheets.
\end{abstract}

Keywords: extract orange, electric, source study

\section{PENDAHULUAN}

Listrik saat ini sudah menjadi sumber kebutuhan utama manusia, keberadaan listrik tidak dapat lagi dipisahkan dari aktifitas manusia sehari - hari, hampir semua bidang kehidupan manusia membutuhkan listrik. Mulai dari kehidupan rumah tangga sampai kebutuhan perindustrian semua membutuhkan listrik. Sumber listrikpun beraneka ragam. Sumber listrik dapat berupa listrik sekala besar dengan tenaga air, nuklir, angin, matahari, minyak bumi, gas alam, gas dari pembuangan limbah mamalia hingga berbagai batuan mineral alam.

Peran batuan mineral alam dalam menjadi sumber listrik cukup besar. Batuan mineral alam dimanfaatkan menjadi sumber listrik yang umum disebut dengan batu beterai, ataupun dimanfaatkan sebagai bahan bakar pembangkit listrik sekala besar. Batuan mineral alam yang selama ini dimanfaatkan antara lain granit, batu bara dan karbon. Batuan mineral alam tersebut dibuat menjadi sumber tegangan dalam bentuk sel kering, ataupun bentuk yang lainnya. Pemenfaatan batuan mineral alam menjadi sumber listrik berawal dari percobaan Galvani dan penelitian Alexander Volta, hasil dari percobaan tersebut kemudian dikenal sebagai sel sederhana. Sel sederhana bekerja dengan prinsip sebuah anode - larutan larutan - dan sebuah katode. Larutan yang digunakan dalam sel sederhana adalah larutan asam yang kemudia larutan asam itu diganti oleh batu mineral alam.

Seiring dengan berjalannya waktu keberadaan batuan mineral di alam semakin menipis, maka mulailah para ilmuan berinovasi menciptakan sumber listrik yang ramah lingkungan dan menggunakan bahan yang mudah diperoleh serta termasuk dalam sumber daya yang dapat diperbaharui. Salah satu hasil inovasi sumber listrik 
alternatif yang sudah berhasil ditemukan adalah sumber listrik dari buah jeruk. Buah jeruk dipilih karena buah jeruk memiliki kemampuan menghantarkan listrik yang baik, hal ini dikarenakan buah jeruk memiliki kandungan asam yang lebih banyak dibandingkan beberapa buah lain yang juga memiliki kandungan asam yang ditandai dengan nilai $\mathrm{pH}$ yang kecil. Alasan lain terpilihnya buah jeruk menjadi bahan sumber listrik adalah karena buah jeruk keberadaanya cukup melimpah, mudah didapatkan, berbuah sepanjang tahun, harganya relaif murah, dan termasuk sumber daya alam yang dapat diperbaharui.

Berdasarkan penelitian yang telah dilakukan oleh Supriyadi (2001:223) tentang sumber listrik alternatif dari buah jeruk sebelumnya, pemanfaatan buah jeruk menjadi sumber listrik dilakukan dengan membuat sayatan pada permukaan buah jeruk hingga menembus kedalam buah jeruk. Kemudian disayatan tersebut ditancapkan dua buah logam yang memiliki sifat berbeda, dua buah logam tersebut adalah seng sebagai anode dan tembaga sebagai katode. Setelah itu dua buah logam itu dihubungkan dengan lampu menggunakan kabel penghubung. Logam dipilih sebagai kompenen percobaan karena logam memiliki sifat sebagai penghantar listrik yang baik.

Penelitian tentang sumber listrik dari buah jeruk baru memanfaatkan buah jeruk secara langsung, namun belum mengambil sari buahnya, padahal sari buah jeruk juga mengandung asam, jika pada buah jeruk cairan asam yang terkandung masih terbungkus oleh pulir buah, asam dalam sari jeruk sudah berbentuk larutan sepenuhnya. Indonesia memiliki beberapa varietas jeruk yang banyak di budidayakan antara lain jeruk nipis, jeruk siam, jeruk keprok, jeruk purut dan jeruk bali. Semua varietas jeruk tersebut memiliki potensi yang berbeda dalam menjadi sumber listrik dikarenakan semua varietas jeruk tersebut miliki tingkat keasaman yang berbeda. Berdasarkan keadaan tersebut sebaiknya di dalam sumber belajar perlu adanya pemanfaatkan sumber belajar yang terdapat di alam, dengan adanya sumber belajar dari sari jeruk yang dapat menghasilkan tegangan listrik, akan membangun karakter peserta didik, rasa ingin tahu peserta didik akan semakin tinggi, dengan konsep yang nyata yang terdapat di alam. Sumber belajar yang dibuat berupa LKS.

\section{METODE PENELITIAN}

Penelitian ini adalah penelitian eksperimen berupa pengidentifikasian potensi dari berbagai macam varietas sari buah jeruk untuk mengetahui potensinya dalam menjadi listrik yang dilakukan dengan melakukan pengujian tegangan yang terkandung dalam sari buah jeruk dari verietas yang berbeda, dan pada akhirnya peneliti dapat mengetahui potensi sari buah jeruk dalam menjadi listrik serta varietas yang paling unggul dalam menjadi listrik. Dalam percobaan ini tegangan yang diidentifikasi karena tegangan merupakan indikasi utama dan yang paling umum diketahui kebanyakan orang tentang suatu hal dapat menjadi listrik.

Penelitian ini dilakukan dengan empat tahap yaitu pengambilan sari buah, pengujian sari buah berbagai varietas sari jeruk, pengujian volume sari buah yang digunakan, pengujian jarak antar elektroda, pengukuran $\mathrm{pH}$ sari buah dan pengukuran kekentalan sari buah. Setelah potensi listrik dari sari jeruk yang berbeda varietas teridentifikasi dan diperoleh varietas yang paling unggul maka hasil penelitian dapat dimanfaatkan sebgai sumber belajar. 
Terdapat 5 perlakuan dan 5 pengulangan yang akan digunakan dalam percobaan ini. Data yang diperoleh dalam penelitian ini dianalisis menggunakan analisis varians Non- parametrik 1 yaitu dengan Uji Kruskal-Wallis. Dalam menganilisis sumber belajar yang dihasilkan sebagai bagaian dari pemanfaatan dari hasil penelitian ini dilakukan dengan Uji kelayakan. Uji kelayakan dilakukan oleh pakar yaitu guru bidang studi fisika smp menggunakan aspek dan kriteria penilaian sumber belajar (Umawah, 2014). Tahapan selanjutnya adalah mengenalisis data yang diperoleh berdasarkan uji ahli menggunakan analisis deskriptif-kualitatif.

Uji kelayakan yang dilakukan oleh ahli dan mengandung kriteria isi materi, Kriteria kebahasaan, dan Kriteria penyajian. Tahapan akhir yang dilakukan dalam menganalisis sumber belajar adalah perbaikan.

\section{HASIL DAN PEMBAHASAN}

Data hasil penelitian yang dipeoleh dalam percobaan ini akan diuraikan dan dibahas dalam penjelasan dibawah ini.

\section{Hasil Penelitian}

Berdasarkan penelitian yang telah dilakukan diperoleh nilai rata-rata tegangan listrik dari sari jeruk berbeda varietas, nilai rata-rata tegangan listrik sari jeruk berbeda jarak antar elektrode berdasarkan perbedaan varietas, dan nilai tegangan rata-rata sari jeruk tegangan listrik sarijeruk berbeda volume berdasarkan perbedaan varietas. Hasil penelitian tersebut disaikan dalam tabel 1, 2 dan 3.

Tabel 1. Tegangan listrik sari jeruk berbeda varietas.

\begin{tabular}{|c|c|c|c|c|c|}
\hline \multirow{2}{*}{ Varietas } & \multicolumn{5}{|c|}{ Tegangan listrik / Tegangan listrik ( volt) } \\
\cline { 2 - 6 } & $\begin{array}{c}\text { Jeruk } \\
\text { Siam }\end{array}$ & $\begin{array}{c}\text { Jeruk } \\
\text { Nipis }\end{array}$ & $\begin{array}{c}\text { Jeruk } \\
\text { Bali }\end{array}$ & $\begin{array}{c}\text { Jeruk } \\
\text { Keprok }\end{array}$ & $\begin{array}{c}\text { Jeruk } \\
\text { Purut }\end{array}$ \\
\hline 1 & 0,902 & 1,866 & 1,23 & 0,78 & 1,4 \\
\hline 2 & 0,901 & 1,87 & 1,2 & 0,779 & 1,41 \\
\hline 3 & 0,9 & 1,86 & 1,21 & 0,781 & 1,42 \\
\hline 4 & 0,903 & 1,85 & 1,17 & 0,782 & 1,43 \\
\hline 5 & 1,253 & 1,865 & 1,606 & 0,905 & 1,829 \\
\hline$\sum \mathrm{X}$ & 4,859 & 9,311 & 6,616 & 4,027 & 7,489 \\
\hline$\overline{\mathrm{X}}$ & 0,97 & 1,86 & 1,32 & 0,8 & 1,5 \\
\hline
\end{tabular}


Tabel 2. Tegangan listrik sari jeruk berbeda jarak antar elektroda berdasarkan perbedaan varietas.

\begin{tabular}{|c|c|c|c|c|c|}
\hline \multirow{2}{*}{ Varietas } & \multicolumn{5}{|c|}{ Tegangan listrik ( volt) } \\
\hline & $\begin{array}{l}\text { Jeruk } \\
\text { Siam }\end{array}$ & $\begin{array}{l}\text { Jeruk } \\
\text { Nipis }\end{array}$ & $\begin{array}{c}\text { Jeruk } \\
\text { Bali }\end{array}$ & $\begin{array}{c}\text { Jeruk } \\
\text { Keprok }\end{array}$ & $\begin{array}{l}\text { Jeruk } \\
\text { Purut }\end{array}$ \\
\hline $1 \mathrm{~cm}$ & 007 & 186 & 132 & 08 & 15 \\
\hline $2 \mathrm{~cm}$ & 0,88 & 1,8 & 1,11 & 0,76 & 1,33 \\
\hline $3 \mathrm{~cm}$ & 0,87 & 1,72 & 1,11 & 0,75 & 1,3 \\
\hline $4 \mathrm{~cm}$ & 0,86 & 1,63 & 1,03 & 0,74 & 1,24 \\
\hline $5 \mathrm{~cm}$ & 0,83 & 1,31 & 1,01 & 0,73 & 1,16 \\
\hline$\sum \mathrm{X}$ & 4,41 & 8,32 & 5,58 & 3,78 & 6,53 \\
\hline$\overline{\mathrm{X}}$ & 0,882 & 1,664 & 1,116 & 0,756 & 1,306 \\
\hline
\end{tabular}

Tabel 3. Tegangan listrik sari jeruk berbeda volume berdasarkan perbedaan varietas.

\begin{tabular}{|c|c|c|c|c|c|}
\hline \multirow{2}{*}{ Varietas } & \multicolumn{5}{|c|}{ Tegangan listrik ( volt ) } \\
\cline { 2 - 6 } & $\begin{array}{r}\text { Jeruk } \\
\text { Siam }\end{array}$ & $\begin{array}{r}\text { Jeruk } \\
\text { Nipis }\end{array}$ & $\begin{array}{c}\text { Jeruk } \\
\text { Bali }\end{array}$ & $\begin{array}{c}\text { Jeruk } \\
\text { Keprok }\end{array}$ & $\begin{array}{c}\text { Jeruk } \\
\text { Purut }\end{array}$ \\
\hline $10 \mathrm{ml}$ & 0,58 & 1,4 & 0,82 & 0,55 & 0,88 \\
\hline $20 \mathrm{ml}$ & 0,6 & 1,4 & 0,89 & 0,58 & 0,9 \\
\hline $30 \mathrm{ml}$ & 0,64 & 1,5 & 0,97 & 0,63 & 0,95 \\
\hline $40 \mathrm{ml}$ & 0,78 & 1,6 & 1,02 & 0,76 & 1,03 \\
\hline $50 \mathrm{ml}$ & 0,97 & 1,86 & 1,32 & 0,89 & 1,5 \\
\hline$\sum \mathrm{X}$ & 3,57 & 7,76 & 5,02 & 3,41 & 5,26 \\
\hline$\overline{\mathrm{X}}$ & 0,714 & 1,552 & 1,004 & 0,682 & 1,052 \\
\hline
\end{tabular}

Berdasarkan data tabel 1 dapat diketahui bahwa pada pengujian sari buah jeruk berbeda varietas dengan volume dan jarak antar elektroda yang disamakan diketahui bahwa sari buah jeruk nipis memiliki tegangan listrik yang tertiggi. Nilai tegangan listrik tertinggi masing-masing sari jeruk adalah sari jeruk nipis 1,87 , sari jeruk pururt 1,829 , sari jeruk bali 1,806 , sari jeruk siam 1,253, dan sari jeruk keprok 0,905 .
Berdasarkan data tabel 2 dapat diketahui bahwa sari buah jeruk dengan jarak antar elektrode yang berbeda diketahui bahwa jeruk nipis memiliki tegangan listrik yang tertinggi. Dimana nilai tegangan listrik tertinggi yang diperoleh masingmasing sari jeruk adalah sari jeruk nipis 1,86 , sari jeruk purut 1,5 , sari jeruk bali 1,32, sari jeruk siam 0,97, dan sari jeruk keprok 0,8 . 
Berdasarkan data pada tabel 3 diketahui bahwa volume sari jeruk nipis memiliki tegangan yang tertinggi, nilai tegangan rata-rata tertinggi yang diperoleh masing-masing sari jeruk adalah sari jeruk nipis 1,86 , sari jeruk purut 1,5 , sari jeruk bali 1,32, sari jeruk siam 097, dan sari jeruk keprok 0,89.

Data hasil penelitian kemudian digunakan untuk menguji hipotesis penelitian. Terdapat empat hipotesis dalam penelitian ini, dua hipotesis diuji menggunakan analisis kuantitatif memakai rumus anava non-parametrik dan dua hipotesis diuji menggunakan analisis deskriptif kualitatif.

Hipotesis yang diuji menggunakan analisis kuantitatif dalam penelitian ini yaitu:

a. Ada pengaruh perbedaan varietas sari buah jeruk menjadi listrik.

b. Sari buah jeruk nipis terunggul menjadi listrik.

Sedangkan dua hipotesis diuji menggunakan anlisis deskriptif kualitatif. Analisis deskriptif-kualitatif merupakan suatu teknik yang menggambarkan dan menginterpretasikan arti data-data yang telah terkumpul dengan memberikan perhatian dan merekam sebanyak mungkin aspek situasi yang diteliti pada saat itu, sehingga memperoleh gambaran secara umum dan menyeluruh tentang keadaan sebenarnya (Rahmawan, 2009). Dua hipotesis yang diuji menggunakan anlisis deskriptif kualitatif dalam penelitian ini yaitu:

a. Pada bagian proses terjadinya tegangan listrik yang dapat dijadikan sebagai sumber belajar.

b. Penelitian ini menghasilkan sumber belajar berupa lembar kerja siswa.

Berdasarkan hasil pengujian hipotesis satu diperoleh kesimpulan dalam percobaan ini tolak $\mathrm{H} 0$ bahwa tidak terdapat pengaruh perbedaan varietas terhadap potensi sari buah jeruk sebagai listrik, karena hasilnya x2hitung > x2tabel pada $\alpha 0.05$ pada table chisquare, yaitu nilai xzhitung adalah 20,98 dan nilai xatabel 0,711 dengan demikian $\mathrm{H} 1$ diterima bahwa ada pengaruh perbedaan varietas terhadap potensi sari buah sebagai listrik. Dalam percobaan ini tolak $\mathrm{H} 0$ bahwa tidak terdapat pengaruh perbedaan varietas sari jeruk yang berbeda jarak antar elektrodenya terhadap potensinya sebagai listrik, karena hasilnya $x$ hitung $>$ xatabel pada $\alpha 0.05$ pada table chisquare, yaitu nilai x2hitung adalah 21,43 dan nilai x2tabel 0,711, dengan demikian $\mathrm{H} 1$ diterima bahwa ada pengaruh perbedaan varietas yang jarak antar elektrodenya berbeda terhadap potensi sari buah sebagai listrik. Dalam percobaan ini tolak $\mathrm{H}_{0}$ bahwa tidak terdapat pengaruh perbedaan volume sari jeruk berbeda varietas terhadap potensi sari buah jeruk sebagai listrik, karena hasilnya xzhitung > xatabel pada $\alpha$ 0.05 pada table chi-square, yaitu nilai x 2 hitung adalah 17,73 dan nilai $x$ 2tabel 0,711, dengan demikian H1 diterima bahwa ada pengaruh perbedaan varietas dengan volume berbeda terhadap potensi sari buah sebagai listrik.

Berdasarkan pengujian hipotesis dua diperoleh kesimpulan bahwa jeruk Sari buah jeruk nipis memiliki potensi listrik yang paling unggul diantara 
varietas yang ada hal ini dipengaruhi oleh $\mathrm{pH}$ yang terkandung didalamnya. Berdasarkan uji anava non parametrik Kruskal Wallis berdasarkan perbedaan varietas, jarak antar elektroda, dan volume selalu menempati rengking tertinggi.

Berdasarkan hipotesis dua dan tiga bagian yang dapat dikembangkan menjadi sumber belajar adalah nilai $\mathrm{pH}$ masing-masing varietas sari jeruk, proses pengukuran tegangan listrik, hasil serta proses terjadinya listrik. Penelitian berupa sumber belajar dapat dikembangkan di dalam Lembar Kerja Siswa (LKS) materi arus listrik alternatif.

\section{Pembahasan Hasil Penelitian}

Hasil yang diperolah dalam penelitian akan dijabarkan dalam pembahasan berikut ini. Penelitian pertama dilakukan dengan membedakan varietas sari jeruk namun jarak antar elektrode dan volume yang digunakan dibuat sama. Berdasarkan data perhitungan pertama yang dilakukan dengan membedakan varietas yang digunakan hipotesis pertama mengenai adanya pengaruh perbedaan varietas terhadap tegangan listrik sari buah jeruk sebagai listrik terbukti atau dapat diterima dikarenakan dalam pengujian tersebut syarat dapat diterimanya hipotesis tersebut terpenuhi, yaitu $\mathrm{H} 1$ diterima bahwa ada pengaruh perbedaan varietas terhadap potensi sari buah jeruk sebagai listrik karena hasilnya $x 2$ hitung $20,98>x 2$ tabel 0,711 pada $\alpha 0.05$ pada table chisquare.
Varietas jeruk yang berbeda dapat mempengaruhi tegangan listrik sari jeruk dalam menjadi listrik hal itu dikarenakan dalam setiap sari jeruk memiliki kandungan $\mathrm{pH}$ yang berbeda, dalam percobaan ini $\mathrm{pH}$ mempengaruhi terjadinya perbedaan potensi listrik yang dihasilkan sari jeruk. $\mathrm{pH}$ menentukan kadar asam yang terkandung dalam suatu buah. Sari jeruk yang memiliki potensi terunggul dalam menjadi listrik adalah yang memiliki kadar asam tertinggi, jeruk nipis memiliki kadar asam terbesar yaitu ditandai dengan $\mathrm{pH}$ terkecil. $\mathrm{pH}$ dapat mempengaruhi tegangan listrik sari jeruk dalam menjadi sumber listrik karena asam mempunyai sifat menghantarkan listrik dimana semakin kuat kadar asam maka ion $H+$ positif yang dimilikinya semakin banyak, sehingga semakin banyak pula ion yang berinteraksi dan baik pula suatu zat dalam menjadi penghantar listrik. Penelitian kedua dilakukan dengan tetap membedakan varietas jeruk yang digunakan namun jarak antar elektrode dibuat berbeda dan volume tetap dibuat sama. Berdasarkan data perhitungan kedua yang dilakukan dengan tetap membedakan varietas serta membedakan jarak antar elektrode yang digunakan (melihat nilai variabilitas total rangking kelompok tegangan listrik sari buah jeruk berbeda varietas) hipotesis pertama mengenai adanya pengaruh perbedaan varietas terhadap potensi sari buah jeruk sebagai listrik terbukti atau dapat diterima dikarenakan dalam pengujian tersebut syarat dapat diterimanya hipotesis tersebut terpenuhi, yaitu $\mathrm{H} 1$ diterima bahwa ada pengaruh 
perbedaan varietas terhadap potensi sari buah jeruk sebagai listrik karena hasilnya hasilnya $x 2$ hitung 21,43> $x 2$ tabel 0,711 pada $\alpha 0.05$ pada table chi-square.

Berdasarkan hasi penelitian tiap perubahan jarak antar elektrode tegangan lsitrik yang dihasilkan juga berubah, dimana semakin berjauhan jarak antar elektrode maka tegangan listrik yang dihasilkan semakin kecil dan semakin dekat jarak antar elektrode maka tegangan listrik yang dihasilkan semakin besar. Dapat dikatakan bahwa jarak antar elektrode berpengaruh terhadap tegangan listrik yang dihasilkan sari jeruk. Jarak $1 \mathrm{~cm}$ merupakan jarak terbaik dalam menghasilkan tegangan listrik. Berdasarkan perhitungan diketahui bahwa jarak atar elektroda yang dekat akan menghasilkan listrik lebih besar. Pengaruh jarak antar ektrode terhadap tegangan listrik sari buah jeruk erat kaitannya dengan medan listrik. Medan listrik terdiri atas garis-garis gaya medan listrik, garis gaya medan listrik merupakan interaksi antara muatan positif dan muatan negativ. Interaksi antara muata positif dan muatan negativ dalam larutan elektrolit menghasilkan sumber listrik. Jarak antar elektode yang dekat menyebabkan interaksi antar muatanmuatan listrik lebih mudah terjadi sehingga medan listrik yang dihailkan semakin besar hal ini menyebabkan tegangan listrik yang dihasilkan semakin besar pula (Giancoli, 2001).

Penelitian ketiga dilakukan dengan tetap membedakan varietas sari jeruk yang digunakan namun volume yang digunakan dibuat berbeda dan jarak antar elektrode dibuat sama. Berdasarkan data perhitungan ketiga yang dilakukan dengan tetap membedakan varietas serta membedakan volume yang digunakan hipotesis pertama mengenai adanya pengaruh perbedaan varietas terhadap potensi sari buah jeruk sebagai listrik terbukti atau dapat diterima dikarenakan dalam pengujian tersebut syarat dapat diterimanya hipotesis tersebut terpenuhi, yaitu H1 diterima bahwa ada pengaruh perbedaan varietas terhadap potensi sari buah jeruk sebagai listrik karena hasilnya hasilnya $x$ hitung $17,73>x 2$ tabel 0,711 pada $\alpha 0.05$ pada table chisquare.

Setiap perubahan volume sari jeruk yang digunakan maka tegangan listrik yang dihasilkan juga berubah. Berdasarkan percobaan diketahui bahwa volume yang lebih banyak akan menghasilkan liistrik yang lebih banyak pula, dimana semakin bertambah volume sari jeruk maka potensilistrik yang dihasilkan semakin tinggi. Volume sari jeruk $50 \mathrm{ml}$ menghasilkan potensi listrik yang lebih besar dibanding volume sari jeruk $40 \mathrm{ml}, 30 \mathrm{ml}, 20 \mathrm{ml}$, dan $10 \mathrm{ml}$. volume sari jeruk 50ml menghasilkan tegangan listrik yang terbesar dan dapat dikatakan terunggul. Berdasarkan perhitungan diketahui bahwa ukuran volume yang banyak menghasilkan listrik lebih besar. Pengaruh volume sari jeruk dalam menghasilkan listrik erat kaitannya dengan jumlah muatanmuatan listrik atau ion-ion yang terkandung dalam sari jeruk, dimana semakin banyak muatan listrik yang terkandung maka interaksi antar 
muatan listrik akan lebih banyak terjadi pula, medan listrik yang terbentuk juga semakin banyak sehingga potensi listrik yang dihasilkan semakin besar (giancoli, 2001). Suatu zat dapat menghantarkan listrik karena zat tersebut memiliki ion-ion yang bergerak bebas di dalam larutan tersebut. Ion-ion inilah yang nantinya akan menjadi penghantar. Semakin banyak ion yang dihasilkan semakin baik pula larutan tersebut menghantarkan listrik.

Hipotesis kedua dalam percobaan ini juga dapat diterima atau terbukti karena berdasarkan data perhitungan mengenai rengking varietas sari jeruk baik yang berbeda varietas, berbeda jarak antar elektrode berdasarkan perbedaan varietas, dan berbeda volume berdasarkan perbedaan varietas, jeruk nipis selalu menempati peringkat pertama hal itu dibuktikan dengan nilai perhitungan tegangan listrik yang diperoleh terkecil yang berarti rengkingnya justru tertinggi. Sari jeruk nipis dapat menghasilkan tegangan listrik terbesar dan selalu menempati rengking tertinggi dipengaruhi oleh kadar asam yang terkandung dalam sari jeruk nipis.

Peringkat yang menunjukkan keunggulan sari jeruk disajikan dalam tabel . Data yang tertera dalam tabel 4 berdasarkan pada perhitungan rengking tiap varietas sari jeruk berbeda varietas, rengking tiap varietas jeruk berdasarkan perbedaan jarak antar elektrode.

Hasil penelitian berupa $\mathrm{pH}$ masingmasing varietas jeruk, massa jenis masing-masing varietas jeruk, dan potensi listrik yang dihasilkan dalam percobaan ini dapat dimanfaatkan sebagai sumber belajar. Setelah data hasil penelitian dianalisis maka cocok dijadikan sumber belajar berupa LKS. Identifikasi bagian penelitian yang berpeluang menjadi sumber belajar tertera dalam tabel 5 .

Tabel 4. Peringkat Sari Jeruk Berbeda Varietas

\begin{tabular}{|r|l|l|r|c|r|r|r|r|}
\hline \multirow{2}{*}{ No } & \multirow{2}{*}{ Varietas } & \multicolumn{6}{|c|}{ Nilai Tegangan dan Rangking } & \multicolumn{1}{c|}{ R } \\
\cline { 3 - 9 } & & $\mathrm{Vj}$ & $\mathrm{R}$ & $\mathrm{vr}$ & $\mathrm{R}$ & $\mathrm{Vv}$ & $\mathrm{R}$ & Rata-rata \\
\hline 1 & Jeruk nipis & 0,6 & 1 & 0,72 & 0,68 & 1 & 0,68 & 1 \\
\hline 2 & Jeruk purut & 1,76 & 2 & 1,64 & 2,12 & 2 & 2,12 & 2 \\
\hline 3 & Jeruk bali & 2,6 & 3 & 2,44 & 2,32 & 3 & 2,32 & 3 \\
\hline 4 & Jeruk siam & 3,6 & 4 & 3,6 & 3,72 & 4 & 3,72 & 4 \\
\hline 5 & Jeruk keprok & 4,44 & 5 & 4,6 & 4,16 & 5 & 4,16 & 5 \\
\hline
\end{tabular}


Tabel 5. Identifikasi Bagian Penelitian yang Menjadi Sumber Belajar.

\begin{tabular}{|c|c|c|c|c|}
\hline No & \multicolumn{2}{|c|}{ Bagian Penelitian } & Kompetensi yang dapat & \\
\hline \multirow[t]{2}{*}{1} & Proses & $\begin{array}{lrr}\text { - Cara mengukur pH sari } \\
\text { jeruk } & \text { masing-masing } \\
\text { varietas, } & \text { volume dan } \\
\text { mencari } & \text { massa jenis sari } \\
\text { jeruk } & \text { masing-masing } \\
\text { varietas. } & \end{array}$ & $\begin{array}{l}\text { - Membaca cara mengukur } \\
\text { pH sari jeruk, memahami } \\
\text { cara mengukur volume, } \\
\text { dan massa jenis. }\end{array}$ & \multirow[t]{2}{*}{$\begin{array}{l}\text { Lembar } \\
\text { kerja } \\
\text { Siswa } \\
\text { (LKS). }\end{array}$} \\
\hline & & $\begin{array}{l}\text { - Cara mencelupkan elektroda } \\
\text { dan mengatur jaraknya } \\
\text { disari jeruk masing-masing } \\
\text { varietas. }\end{array}$ & $\begin{array}{l}\text { - Ketrampilan membedakan } \\
\text { kutub anoda dan katoda. }\end{array}$ & \\
\hline \multirow[t]{2}{*}{2} & Hasil penelitian & $\begin{array}{l}\text { - Data tegangan listrik yang } \\
\text { dihasilkan sari jeruk } \\
\text { berbeda varietas, berbeda } \\
\text { jarak antar elektroda, } \\
\text { berbeda volum, dan data } \\
\text { rengking untuk mencari } \\
\text { varietas sari jeruk terbaik. }\end{array}$ & $\begin{array}{l}\text { - Membaca dan memahami } \\
\text { dengan antusias tegangan } \\
\text { listrik sari jeruk berbeda } \\
\text { varietas, berbeda jarak } \\
\text { antar elektrode, berbeda } \\
\text { volume, dan mengetahui } \\
\text { rengking varietas sari } \\
\text { jeruk }\end{array}$ & \multirow[t]{2}{*}{$\begin{array}{l}\text { Lembar } \\
\text { kerja } \\
\text { Siswa } \\
\text { (LKS) }\end{array}$} \\
\hline & & $\begin{array}{l}\text { - Proses terjadinya sumber } \\
\text { listrik dari sari jeruk. }\end{array}$ & $\begin{array}{ll}\text { - Mendeskripsikan } & \text { proses } \\
\text { teradinya sumber } & \text { listrik } \\
\text { dari sari jeruk. } & \end{array}$ & \\
\hline
\end{tabular}

Langkah selanjutnya setelah dilakukan analisis hasil penelitian secara deskriptif kualitatif dan diperoleh sumber belajar berupa LKS adalah melakukan uji ahli untuk mengetaui kelayakan pengunaan LKS dalam pembelajaran fisika. Terdapat tiga ahli dari tiga SMP berbeda yang melakukan pengujian terhadap sumber belajar ini. Aspek yang diuji ahli berupa aspek isi, apsek kebahasaan dan aspek penyajian.
Lembar uji ahli terdiri atas lima belas pernyataan. Kriteria penyimpulan hasil uji ahli dinyatakan oleh pernyataan layak tanpa revisi, layak dengan revisi, dan layak tanpa revisi. Hasil uji ahli terhadap sumber belajar yang dihasilkan dari penelitian ini terdapat dalam tabel 6 .

Tabel 6. Hasil Uji Ahli Sumber Belajar

\begin{tabular}{|c|c|c|c|}
\hline No & Penguji & Kriteria & Kesimpulan \\
\hline 1 & Ahli 1 & Layak tanpa revisi & $\begin{array}{c}\text { Sumber belajar dapat } \\
\text { digunakan dalam }\end{array}$ \\
\hline 2 & Ahli 2 & Layak dengan revisi & $\begin{array}{l}\text { pembelajaran fisika smp } \\
\text { karena dua ahli menvatakar }\end{array}$ \\
\hline 3 & Ahli 3 & Layak tanpa revisi & layak tanpa revisi. \\
\hline
\end{tabular}


Sumber belajar dalam penelitian ini dapat diterapkan dalam bentuk konsep sebagai berikut.

a. Hasil penelitian ini dapat digunakan sebagai rancangan atau sumber belajar siswa SMP kelas IX semester ganjil.

b. Hasil penelitan ini dapat dimanfaatkan sebagai sumber belajar berupa LKS untuk mengatahui prinsip kerja sumbersumber listrik alternatif.

c. Format sumber belajar sebagai berikut: 1) Sampul berisi judul besar materi yang akan dipelajari, KI, KD. 2) Isi berupa apersepsi, teori yang berkaitan dengan percobaan yang peneliti lakukan, tujuan praktikum, alat dan bahan, langkah kerja, tabel hasil pengamatan, dan kesimpulan. 3) Fungsi sumber belajar ini untuk meningkatkan rasa ingin tau siswa tentang pemanfaatan sumber daya alam yang ada diligkungan sekitar siswa, dan meningkatkan ketertarikan siswa terhadap mata pelajaran fisika. Selama ini sebagian besar dari siswa hanya mengetahui manfaat buah jeruk sebagai bahan makanan namun ternyata buah jeruk juga dapat dimanfaatkan sebagai sumber listrik, dan hal ini tentu sangan menarik bagi pembelajaran fisika di kelas. 4) Implementasinya sebagai suplemen pendidikan fisika SMP materi sumber arus listrik alternatif.

\section{KESIMPULAN}

Berdasarkan hasil penelitian dan analisis data yang peneliti lakukan maka dapat ditarik kesimpulan sebagai berikut:

1. Varietas sari jeruk yang berbeda menghasilkan potensi listrik yang berbeda pula. Ada pengaruh perbedaan varietas sari jeruk terhadap potensinya sebagai listrik. Berdasarkan kriteria uji diperoleh $x$ 2hitung > x2tabel pada $\alpha 0.05$ yaitu nilai $x 2$ hitung adalah 20,98, 21,43, dan 17,73 sedangkan nilai $x 2$ tabel 0,711 .

2. Sari buah jeruk nipis memiliki potensi listrik yang paling unggul diantara varietas yang ada hal ini dipengaruhi oleh $\mathrm{pH}$ yang terkandung didalamnya. Berdasarkan uji anava non parametrik Kruskal Wallis berdasarkan perbedaan varietas, jarak antar elektroda, dan volume selalu menempati rengking tertinggi.

3. Berdasarkan penelitian bagian yang dapat dikembangkan menjadi sumber belajar adalah nilai $\mathrm{pH}$ masing-masing varietas sari jeruk, proses pengukuran tegangan listrik, hasil serta proses terjadinya listrik. Penelitian berupa sumber belajar dapat dikembangkan di dalam Lembar Kerja Siswa (LKS) materi arus listrik alternatif.

\section{SARAN}

Berdasarkan kesimpulan yang diperoleh selama melaksanakan penelitian dan hasil pengamatan dan pelakasanaan penelitian, maka peneliti menyarankan:

1. Disarankan untuk penelitian selanjutnya melakukan pengujian tentang sari jeruk berbeda varietas untuk mencari stabilitasnya dan ketahanaannya dalam menghasilkan listrik setelah sari jeruk diperas dan didiamkan dalam waktu yang lama.

2. Disarankan untuk penelitian selanjutnya melakukan pengujian tentang sari jeruk berbeda varietas menjadi bentuk pasta dan ditempatkan pada tempat yang permanen agar lebih mudah digunakan dan praktis. 
3. Untuk guru disarankan agar memanfaatkan hasil penelitian ini menjadi bentuk sumber belajar alternatif.

\section{DAFTAR PUSTAKA}

Giancoli, douglas c. 2001. Fisika Dasar Jilid 2 Edisi Kelima. Jakarta: Erlangga.

Rahmawan, Tizar. 2009. Contoh Proposal Penelitian Kualitatif (online).10 juni (http://tizarrahmawan.wordpress. com/2009/12/09/contohproposal-penelitiankualitatif/diaksespadatanggal 20 agustus 2014 pukul 22.00 WIB).

Supriyadi. 2001. Panduan untuk Merancang Eksperimen Sederhana. yogyakarta : tempelsari publishing company.

Winarsunu, Tulus. 2009. Statistik Dalam Penelitian Psikologi dan Pendidikan. Malang: UMM press. 